lectual 'System'" (also published in the Annals of the American Academy of Political and Social Science, September 1975), Philip G. Altbach, State University of New York at Buffalo, describes the critical role books continue to play in the intellectual system of most societies. The other general paper, by the editor, William L. Williamson, is "Comparative Studies: Onions? or the Emperor's New Clothes?" and contains some general remarks about comparative studies.

Even though it makes no pretense of giving us definitive studies, this little volume can prove useful as a compilation of several case studies. But one wishes Williamson had converted his remarks into a general introductory essay, thus indicating at the outset the methodological basis of the Wisconsin seminar, instead of leaving the readers to discover it for themselves.

The inclusion of maps would have been a helpful addition; and despite the note advising that the volume contains "an edited version" of the papers, there is some inconsistency in footnote style, and some citations appear to be incomplete. Nevertheless, the Library School at Madison deserves commendation for making available a series of papers useful to those interested in comparative librarianship.-William Vernon Jackson, The University of Texas at Austin.

Johnson, Elmer D., and Harris, Michael H. History of Libraries in the Western World. 3d ed., completely revised. Metuchen, N.J.: Scarecrow, 1976. 354p. $\$ 10.00$. LC 76-25422. ISBN $0-8108$ 0949-4.

The first edition of this familiar work appeared in 1965 as a transmogrification of a still earlier Johnson book published by Scarecrow Press ten years before. It represented a unique attempt to provide a survey of the spread and expansion of libraries from earliest times in Europe and the United States. Its success as a text in library schools led to a second edition expanded to include developments in Canada and Latin America. Its publisher, however, soon discovered that more was not better: the higher cost, the sheer bulk of 521 pages, and the repetitious nature of the contents made the second edition a much less attractive commodity.

As a result, Michael Harris (University of Kentucky Library School) was called in to perform surgery. In terms of the immediate goal of reducing its size, the third edition succeeds handsomely. With only 354 pages, it is slimmer than even the first edition and sells for $\$ 2.50$ less than its predecessor. It achieves this by the adoption of a more efficient format that crowds 20 percent more words onto a page, by the elimination of some sections altogether (those dealing with modern private libraries, for example), by vigorously pruning reading lists at the end of each chapter, and by severely cutting the index to a quarter of its previous size.

But alas, less is not necessarily all that better, either. The updating of the reading lists and the deletion of obsolete and not readily accessible entries that padded earlier editions are perhaps the most positive results. The book itself falls considerably short of success both in terms of its overall style and presentation as well as in the very way in which it conceives of its subject.

It may be questionable for this journal to subject to very close scrutiny a textbook, particularly one claiming no pretentions to serious scholarship. But it is worth considering some flaws in what may still be considered as one of the more useful texts because they reflect characteristic shortcomings, not only of library history as it has been written, but of the kind of tedious courses to which library school students are often subjected.

Despite the publisher's claim, the book has not been "completely revised in the light of recent advances." There has been some tinkering with transitional sentences, some dropping of paragraphs here and there. There has been a good deal of scissors-and-paste rearrangement. But the book, for the most part, has not been recast or rewritten except in the most superficial sense. Overall it is still-what its pedestrian style has never disguised-a dry, enumerative account of the establishment through time of "organized collections of graphic materials."

It takes its reader from country to country and from century to century through 
the original author's card file of salient data on most of the "libraries" known to have existed outside of Asia; from caches of cuneiform tablets in Mesopotania to the shelves of religious literature in nineteenth century American Sunday schools; from the museum of Alexandria to the Library of Congress. One finds dates of founding, numbers of volumes, names of principal benefactors, descriptions of regulations, and physical layout.

Only occasionally does one get a sense of "development" that means anything but growth in size and numbers. In short, as a form of history it fails to rise above the level of chronicle.

Moreover, the newest edition attempts to foster an illusion of having updated the statistics of which its treatment of the recent past largely consists. The data produced in the earlier edition stubbornly remain; the phrase "in the 1960s," however, now reads "in the seventies" in order to convey, quite erroneously, the currency of the statistics. Some sections badly needing revision did not get it. (The section on Latin America, to cite but one example, while shortened by simply dropping earlier paragraphs on Paraguay, Colombia, Peru, and Venezuela, leaves glaring obsolete treatment of Chile and Argentina virtually intact.) There are some curious omissions: no sense of modern librarianship as a profession, little appreciation for the development of library architecture. The continued exclusion of the Far East from such an otherwise broad survey seems as quaint as it does arbitrary. There is virtually no attention given to the technological developments of the last decade.

Not surprisingly, the book's usefulness diminishes as it approaches the present. More seriously, when the authors move beyond statistics to the organic relationship between libraries and the societies in which they exist, their treatment is often unimaginative or downright naive. The new edition still concludes with the same banal essay on the role of libraries which appeared in each of its predecessors. In fact, neither author has really succeeded in getting at the real role of libraries and how societies are different because of them.

In sum, it is an old-fashioned approach that suffers by comparison with recent works in library history, especially those appearing in conjunction with the American Bicentennial that called attention to the richness the field holds for its students and the greater sophistication in handling the subject deserves.-W. A. Moffett, Director of Libraries, State University of New York, College at Potsdam.

Jarvi, Edith. Access to Canadian Government Publications in Canadian Academic and Public Libraries. Ottawa: Canadian Library Association, 1976. 116p. \$12.00.

This is a report of a preliminary study undertaken in 1975 by the Canadian Library Association to determine how well academic, public, and community college libraries make accessible to their publics government information in the form of publications. In doing this, the study relates two aspects of government publications activity: the state of bibliographical control of Canadian government publications both national and provincial; and the role of the libraries in the procurement, handling, and

\section{YOU WILL HAVE- "GONFIDENGE"}

\section{In Our Complete Periodicals Service- All American and Foreign Titles}

Promptnoss is a Traditional part of MeGreger Sorvice . . . as woll as:

- EXPERIENCE

- TRAINED PERSONNEL

- finANCIAL STABILITY

- AMPLE FACILITIES

- RESPONSIBLE MANAGEMENT

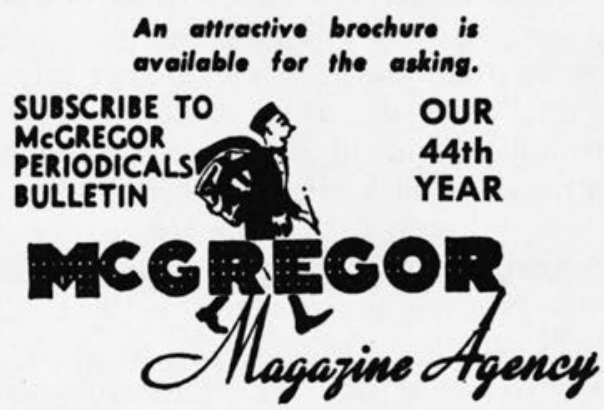

MOUNT MORRIS, LLINOIS 61054 